UDC 658:621.339.15

S. Tulchynska, Dr. Sc. (Econ.), Prof., orcid.org/0000-0002-1409-3848,

N. Shevchuk, Cand. Sc. (Tech.), Assoc. Prof., orcid.org/0000-0003-0355-9793,

V. Chornii, Cand. Sc. (Econ.),

orcid.org/0000-0002-4460-0759,

B. Chornii, Cand. Sc. (Econ.),

orcid.org/0000-0002-4736-7833

\title{
USING A METHODICAL APPROACH TO THE EVALUATION OF ATTRACTIVENESS INVESTMENT RESOURCES FOR ELECTRICITY DISTRIBUTION COMPANIES
}

Purpose. To substantiate the methodological approach to the evaluation of investment resources at the enterprise of electric energy distribution in the conditions of diversifying their sources through the use of nonlinear dynamics model by M. Magnitsky.

Methodology. The study used systematic and synergetic approaches as well as the method of analytical modeling.

Findings. The work proved the use of nonlinear dynamics model by M. Magnitsky for evaluation of investment projects; a structural diagram of the algorithm calculating the efficiency of project companies for the electric energy distribution based on the nonlinear dynamics model by M. Magnitsky was suggested. The methodical approach to the evaluation of investment resources through the use of nonlinear dynamics model by M. Magnitsky has practical value for the businesses of energy distribution and other businesses, and gives an opportunity to determine the effectiveness of the project under the conditions of diversification of sources of funds available for investment.

Originality. This article suggests the improved methodological approach to the evaluation of investment project efficiency of enterprises of electric energy distribution on the cognitive information basis, which involves implementation of: mathematical structural model for calculating the parameters of the investment project and two solutions of differential equations of the model by M. Magnitsky, which, unlike the existing ones, is based on the solution of Feyhembaum' attractors with stabilization of operating points of managing the investment resources based on their diversity.

Practical value. The methodical approach to the evaluation of investment resources can be used at the enterprise of electric energy distribution in the conditions of diversifying their sources.

Keywords: investment funds, the investment project model, nonlinear dynamics, diversification, efficiency

Introduction. Investigation of the problems of attraction of investment resources is in the center of attention of economic science. In modern conditions of increasing threats and risks, attraction of investment resources requires special attention, because the investment serves as the driving force of business and economy. Ukrainian industrial enterprises, including energy distribution enterprises, are mostly characterized by unsatisfactory state of fixed assets, which prompts the activation of the process of attraction of investment resources for their development.

Analysis of the recent research and publications. An important contribution to the development of theoretical principles of the investment processes has been made out by such foreign scientists as: G. Alexander, G. Bailey, J. Bernar, C. Bode, S. Brue, E. J. Dolan, A. Kane, J. C. Colley, D. Lindsey, C. McConnell, A. J. Marcus, W. Sharp and others. Many special studies and publications of Ukrainian scientists have been devoted to the analysis of the state and problems of attraction of investment resources in industrial enterprises of Ukraine, namely, by: I. Blank, V. Bocharov, H. Vozniak, M. Denysenko, A. Duka, S. Illiashenko, O. Kuzmin, V. Marchen-

(C) Tulchynska S., Shevchuk N., Chornii V., Chornii B., 2018 ko, A. Peresada, V.Savchuk, T. Smovzhenko, A. Tereshchenko, D. Chervnov and others. The following works of native scientists-economists have been devoted to the research on the problems of attraction of investment resources for the energy distribution companies: A. Amosha, O. Bilorus, A. Butenko, O. Vovk [1], N. Hordiienko [2], M. Dolishnii, O.Zinchenko [3], A. Kredisov, G. Kozoriz, I. Lukinov, I. Manaienko [4], O. Okhrimenko [5], T. Sihaieva [6], M. Chumachenko and others.

Unsolved aspects of the problems. However, despite a large number of publications on investments, the mechanism of attraction of investment resources provided diversification of their sources into energy distribution companies in conditions of increasing threats and risks is still not developed sufficiently. It concerns theoretical and methodological and applied aspects, including tool for estimating and forecasting the efficiency of investment projects of energy distribution companies that provide external lighting of settlements.

To substantiate the method of attraction of investment resources for the energy distribution company under conditions of diversification of their sources, mathematical modulation is used. At the same time, in today's conditions of growing threats and risks, the approaches to assessing the attraction of investment re- 
sources for the energy distribution company in the conditions of diversification of their sources remain underdeveloped.

Objectives of the article. The purpose of the article is to substantiate the methodical approach to assessing the attraction of investment resources for the energy distribution company in the conditions of diversification of their sources. To achieve this goal, in the work there was:

- substantiated a possibility of using M. Magnitsky's model of nonlinear dynamics for the estimation of investment projects;

- proposed a scheme of the algorithm for calculating the efficiency of the investment project of energy distribution companies based on M. Magnitsky's model of nonlinear dynamics.

Presentation of the main research. For clarity of methodological study, it is proposed to consider attraction of investment resources on an example of investment projects and to substantiate a mathematical model for evaluating the effectiveness of investment projects in the conditions of diversification of sources of investment resources.

To calculate the efficiency of the investment project of energy distribution companies, we propose to use M. Magnitsky's model of nonlinear dynamics.

Nonlinear dynamics develops one of the directions of the economy, namely, the synergetic economy - the branch of economic theory which examines the processes of economic evolution with unstable nonlinear systems in the conditions of rapid variability of their structural transformations and transition to chaos with uncertainty of characteristics. Nonlinear dynamic studies stability of such systems as:

-firstly, the dissipative system (system with a point) in the process of the system evolution, the control is at a certain point that is described by the coordinates of control parameters (unstable control);

-secondly, the conservative system (cycle system) in the process of system evolution, the control is described by a point that is characterized by the coordinates of the control parameters by which the point moves along a closed trajectory or cycle (stable control).

For the dissipative system (such as a system with a control point), the model examines such economic objects as an equilibrium point, an efficiency point, a break-even point, and other points. For the conservative system (such as a system with a cycle), the model examines such economic objects as the cycle of market fluctuations, the cycle of business activity in the investment project, the cycle of repayment of financial payments, and other cycles.

An investment project - as some economic system -involves financial flows and generates the problem of selecting investment objects with the possibility of diversifying sources of investment resources [7]. The study of the investment projects effectiveness and their management in such a system is quite complicated, since many parameters are applied. On the one hand, an investment project must be effective and efficient in terms of its use (application), and, on the other hand, an in- vestment project must be effective in investing resources in terms of minimizing the time limits for its implementation. Thus, an investment project can be considered as a synergetic system that is the object of modeling the system of differential equations.

Therefore, nonlinear dynamics, or the theory of deterministic chaos, is chosen to develop a model for calculating the efficiency of attraction of investment resources in the conditions of diversifying their sources, because it explores systems that have complex behavior in the presence of internal laws of operation. The synergetic approach helps to comprehend the non-linearity of the process of attraction of investment resources, which is demonstrated in the variety of possible developmental trajectories after passing the bifurcation point, taking into account the current conditions of increasing threats and risks.

Magnitsky's model of nonlinear dynamics [7] is formed in terms of two systems of differential equations $(1,2)$, which will be given in the article below.

The first system consists of three nonlinear differential equations (1) and is created to find solutions of such variables in time

$$
\begin{gathered}
\dot{x}_{0.0}(t)=b x_{0.0}\left[(1-\sigma) x_{2.0}-\delta x_{1.0}\right] \\
\dot{x}_{1.0}(t)=x_{0.0}\left[1-(1-\delta) x_{1.0}+\sigma x_{2.0}\right] ; \\
\dot{x}_{2.0}(t)=a\left[x_{1.0}-c x_{0.0}\right],
\end{gathered}
$$

where $x_{0.0}$ is distribution of investment risks under the project; $x_{1.0}$ is distribution of the investor's payments for project provision; $x_{2.0}$ is distribution of profit margins under the project; $x_{0.0} ; x_{1.0} ; x_{2.0}$ is the initial data for calculations; $a$ is the normalized coefficient of reduction of the profit rate on the attracted investment resources; $b$ is the normalized coefficient of reduction of non-payment risks for the given investment project; $c$ is the normalized coefficient of investment capital creation; $\delta$ is the normalized solvency ratio $\left(0<\delta \leq \delta_{0}<1, \delta_{0}=0.9\right.$ is the critical factor of solvency); $\sigma$ is the parameter of management of an investment project ( $\sigma<0$ is commandadministrative (manual) project management under conditions of financing only from the exogenous source of financing; $\sigma>0$ is market management of the project (in terms of financing both from the exogenous and endogenous sources of financing), while $\sigma<1-\delta-$ for the implementation of project management); $\sigma, \delta$ are system control parameters, when the operating point $O(x)$ is selected for project management.

The first two equations of the system of nonlinear differential equations making formula (1) describe the changes and the intensity (diffusion) of investment attraction which requires investment project under the conditions of use of the concession; for example, for the energy distribution companies that provide outdoor lighting for the settlements to replace lighting devices with new LED modules. The third equation determines the change in the rate of profit, which has influences on the change in the effectiveness of investment resources in the project. The change in investment resources in the project generates cash flows in accordance with the 
costs and revenues of the project in the presence of nonpayment risks. The change in the rate of profit affects, in a certain way, the formation of a discount rate in the process of using investment resources. The solution of the system uses the Runge-Kutta method of the order. The effect of the investment resource is determined by a small delay $(\varepsilon<1)$ due to reduction in the rate of profit in the second system.

The results of calculations in this system of investment project management are used to find the strategy of project implementation. When comparing two strategies for implementing an investment project (Strategy-A and Strategy-B), the better strategy is chosen according to a certain criterion.

In general, a certain limit cycle is considered. This is a closed trajectory of solutions of a system of differential equations. The limit cycle appears when there is an enclosure of solutions that is completely filled with trajectories, which eventually approach this cycle indefinitely. The limit cycle is stable if the trajectory approaches it with increasing time. The ordered system consisting of a point and a limit cycle is an attractor. Other derived attractors, such as points, separate trajectory paths breaks, do not meet its objectives, and are not used in the model further.

The application of M.Magnitsky's mathematical model allows us to detect the Feigenbaum attractor, to find out all points and cycles, and to stabilize the solutions found in the form of points and cycles. The solutions and parameters of the model in the economic sense correspond to the input characteristics of the investment project, which are calculated on the basis of reports and appropriate cost estimates for preparation for the investment project.

In the case when the point is unstable (the attractor of Feigenbaum $\left(X^{(2)}-X^{(1)}\right)$ may have gaps or does not have closed trajectories at all), then stabilization of the fixed control point of Feigenbaum $O\left(x_{0.1} ; x_{1.1} ; x_{2.1}\right)$ with the use of the second system of differential equations by the M. Magnitsky's method is carried out for a small delay, since the attraction of the investment resources from another source, for example, due to endogenous resources, with a certain stabilization does not work instantaneously, but after a short period of time.

The second system of differential equations by M. Magnitsky's method has the form

$$
\begin{gathered}
\dot{x}_{0.0}(t)=b x_{0.0}\left[(1-\sigma) x_{2.0}-\delta x_{1.0}\right]+\varepsilon_{0.0}\left(x_{3.0}-\delta\right) ; \\
\dot{x}_{1.0}(t)=x_{0.0}\left[1-(1-\delta) x_{1.0}+\sigma x_{2.0}\right]+\varepsilon_{1.0}\left(x_{3.0}-\delta\right) ; \\
\dot{x}_{2.0}(t)=a\left[x_{1.0}-c x_{0.0}\right]+\varepsilon_{3.0}\left(x_{3.0}-\delta\right) ; \\
\dot{x}_{3.0}(t)=d_{0.0}\left[(1-\sigma) x_{2.0}-\delta x_{1.0}\right]+ \\
+d_{1.0}\left[x_{0.0}\left[1-(1-\delta) x_{1.0}+\sigma x_{2.0}\right]\right]+ \\
+d_{2.0}\left[a\left[x_{1.0}-c x_{0.0}\right]\right]+\mu\left(x_{3.0}-\delta\right)
\end{gathered}
$$

where $d_{0.0}, d_{1.0}, d_{2.0}$ are the coefficients of stabilization in accordance with $x_{2.0}-$ from $x_{1.0}, x_{1.0}-$ from $x_{0.0}, x_{2.0}-$ from $x_{0.0} ; \mu$ is the coefficient of stabilization $x_{3.0}$.

The second system consists of four nonlinear differential equations (2), which is constructed to find solu- tions to the system when the project management point $O(x)$ is stabilized with the coordinates $O\left(x_{0.1} ; x_{1.1} ; x_{2.1}\right)$ corresponding to the first system in the management of an investment project in the conditions of attracting investment resources from exogenous sources using the concession on the found control trajectory.

The fixed point stabilization model provides stable project management conditions beyond which the point does not fall into the uncertainty of management (trajectory failures and discontinuities).

The first two equations describe the stabilization of the point $O\left(x_{0.1} ; x_{1.1} ; x_{2.1}\right)$ (3) due to the effect of the change and the diffusion intensity of the additional attraction of investment resources in the conditions of diversification of their sources, which occurs during a certain period of time.

$$
x_{0.1}=\frac{1-\sigma}{c(1-\delta-\sigma)} ; \quad x_{1.1}=\frac{1-\sigma}{1-\delta-\sigma} ; \quad x_{2.1}=\frac{\delta}{1-\delta-\sigma} .
$$

The third equation determines the stabilization of the change in the rate of profit, under the influence of which there is a change in the capital in the project. Thus, the cash flows in a fixed-risk project are stabilized. The fourth equation stabilizes the distribution of the discount rate $x_{3.0}$ in the process of using investment resources over a certain period of time.

The effect of attraction of investment resources when stabilizing a project management point is not determined immediately, but after some time of using investment resources, so the second system introduces a slight delay in the argument $\varepsilon \ll 1$ by reducing the rate of profit for the corresponding variables: $\varepsilon_{0.0}$ is delay from the action $x_{0.0}, \varepsilon_{1.0}-$ from action $x_{1.0}, \varepsilon_{2.0}-$ from action $x_{2.0}$.

The existence and stability of equilibrium solutions in the system of differential equations explores the theory of bifurcations. A bifurcation point is a special point in the system solutions through which two or more branches of a differential equation pass, which is why the bifurcation indicates a change in the behavior of the system. The most common way to explain the solution of differential equations is to use the Hopf bifurcation, which we use in analyzing solutions of differential equations.

For economic calculations and characteristics of concession project of attracting investment resources in the conditions of their source diversification, as well as calculation of its efficiency for future use, mathematical methods of analysis of economic systems are used. Solutions of the second system are to be used in the future to calculate the efficiency of the project for the NPVmethod.

The mechanism of attraction of investment resources is influenced by various factors under the current conditions of increasing threats and risks, resulting in chaotic changes that are difficult or even impossible to foresee in advance. Magnitsky's model of nonlinear dynamics takes into account the similar behavior of such complex systems.

Given an attractor, trajectory and management points, two variants of the project implementation strategies are considered: A - with the attraction of invest- 
ment resources from the endogenous source for the use of the concession; B - for the diversification of sources of investment resources at the expense of exogenous sources under concession terms. Within Strategy B, two options are considered for project implementation and the better option for the project is selected [8].

To compare different strategies of an investment project there can be used the criteria by Wald, Hurwitz, Laplace, Savage and other criteria. For example, the application of the Wald criterion is justified if the situation has the following circumstances: the external state of the system is uncertain, the implementation of the solution occurs only once; there is a need to exclude any risk. Wald's criterion is based on the principle of the largest maximum or minimum limit and determines the best or worst decision in terms of increasing risk. Since the application of the MM - criterion (Walt's minimum criterion) is justified, if the situation has the following circumstances: the external state of the system is uncertain, the implementation of the solution occurs only once and there is a need to exclude any risk. Therefore, the application of the Laplace's criterion, in particular, is the most justifiable. Other criteria represent only one result on which the decision is made, and Laplace's criterion takes into account each of the possible consequences in making decisions by averaging the intermediate values of the data obtained in the strategies for implementing the investment project. The Laplace's criterion is based on the Laplace's inadequate basis principle according to which all economic indicators are equally important. In this case, each state of the investment project is given by the probability $(q)$, calculated by the formula

$$
q_{i}=\frac{1}{n},
$$

where $n$ is the number of possible values of indicators of the efficiency of investment projects.

The estimated data is used to calculate the effectiveness of the investment project and forecast the costs of servicing the objects of the concession project for the subsequent period.

The Feigenbaum's attractor $\left(X^{(2)}-X^{(1)}\right)$ of shows the nature of the investment project management area, where $X^{(2)}-X^{(1)}-$ the data sets of the calculations that characterize this attractor.

A solution is found that reproduces closed control paths. Trajectories in the form of the following objects: separate arcs, a set of points, a separate cycle are not used for further calculation of parameters of the investment project.

The block diagram of the algorithm for calculating the efficiency of the investment project for energy distribution companies on the basis of M. Magnitsky's model of nonlinear dynamics is proposed in Figure.

After finding the solution of M. Magnitsky's model of nonlinear dynamics formed in the form of two differential systems, we calculate the effectiveness of the investment project by the following indicators, such as:

1) NPV - net present value from the project;

2) PI - profitability index of the project;

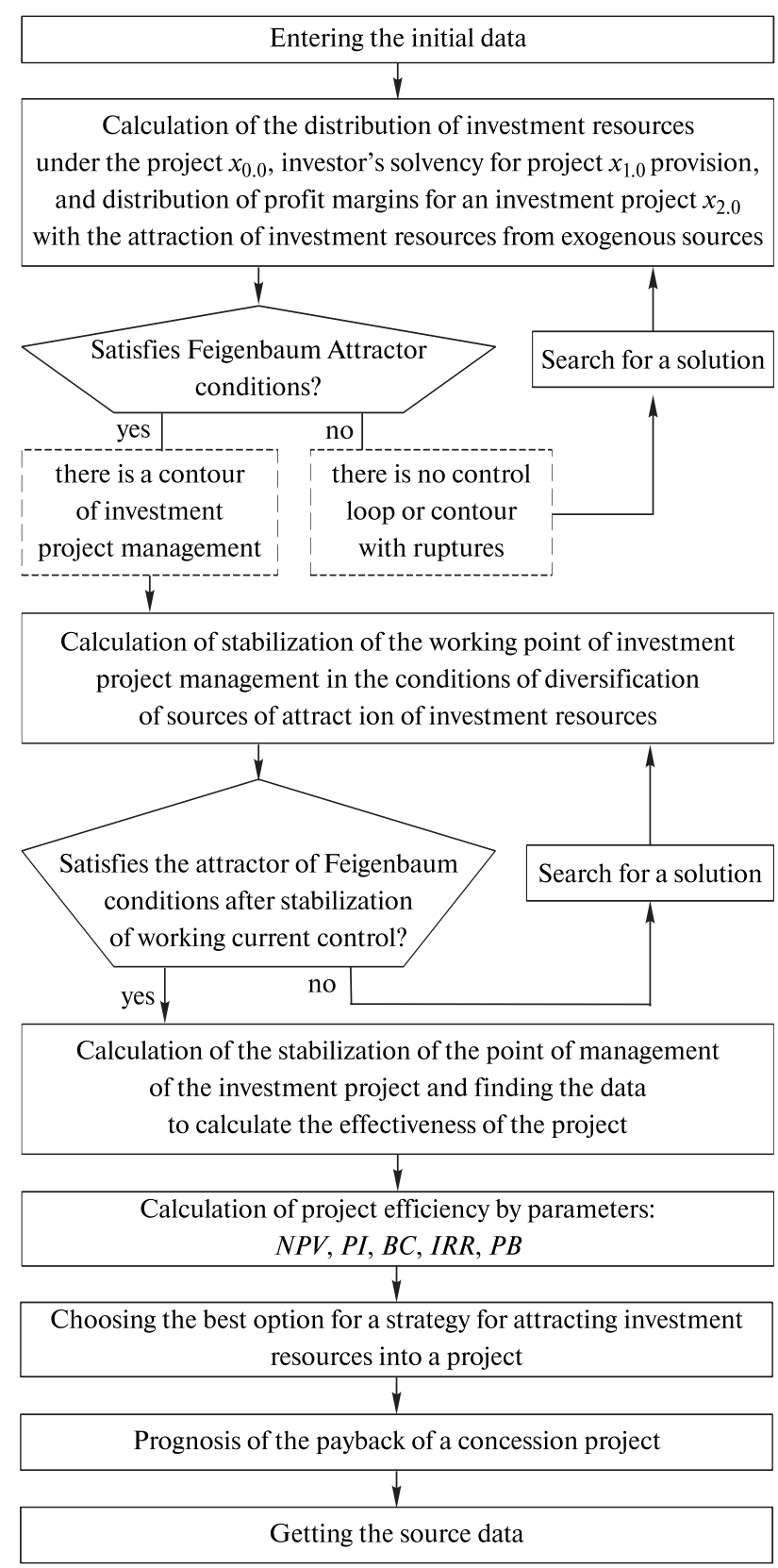

Fig. Structural scheme of the algorithm for calculating the effectiveness of the investment project in the conditions of diversification of sources of investment resources

3) $\mathrm{BC}$ - the ratio of benefits to costs of the project;

4) IRR - internal rate of return of the project;

5) PB - discounted payback period of the project.

Besides, the forecasting of the costs of servicing objects of the concession project for the subsequent period is carried out. The calculations are carried out for strategy $B$, that is, with diversification of sources of investment resources at the expense of exogenous sources under concession terms, where the first option - without stabilizing the Feigenbaum's management point, the second option - with the stabilization of the project management point.

According to the developed scheme of the algorithm for calculating the effectiveness of the investment proj- 
ect, based on M. Magnitsky's model of nonlinear dynamics, the following is determined: net present value from the project; profitability index of the project; the ratio of benefits to costs of the project; internal rate of return of the project; discounted payback period of the project, as well as forecasting costs of servicing objects of the concession project for the subsequent period.

Conclusions and recommendations for further research. Thus, the proposed structural scheme of the algorithm for calculating the efficiency of the investment project of electricity distribution companies on the model of nonlinear dynamics of M.A. Magnitsky, according to which the calculated data obtained as a result of the solutions of two systems of differential solutions of the model of nonlinear dynamics of M.A. Magnitsky, are used to calculate the effectiveness of the investment project, namely: the net reduced revenue from the project; profitability index of the project; benefit ratio to project costs; the internal rate of payback of the project; discount period of payback for construction of the Scurve Fisher-Pray. Moreover, the forecasting of expenses for servicing objects of the concession project for the subsequent period is carried out.

In order to calculate the efficiency of an investment project in the conditions of diversification of sources of investment resources of electricity distribution companies providing external illumination of settlements, it is proposed to use the model of nonlinear dynamics of M.A. Magnitsky, and the investment project is considered as a synergetic system that is the object of modeling the system of differential equations. Nonlinear dynamics develops a synergetic economy that considers the processes of economic evolution with nonlinear systems and helps to grasp the non-linearity of the process of attracting investment resources to the electricity distribution company in the conditions of their source diversification.

Further research in this area consists in approbation of a cognitive-information-based methodical approach to assessing the efficiency of investment projects of electricity distribution companies in the conditions of their diversification.

\section{References.}

1. Vovk, O. M., 2014. The theoretical basis for effective management of investment resources. Vodnyj transport : zb. nauk. prats, 1(19), pp. 106-109.

2. Gordienko, N. M., 2013. The content of the investment policy of an industrial enterprise. News from higher educational institutions. Sociology. Economics. Politics, 2, pp. $65-67$.

3. Zinchenko, O.A. and Zinchenko, D. S., 2016. Economic development of enterprises and economic results of the company: relationship, evaluation and simulation features. Suchasni problemy ekonomiky i pidpryiemnytstvo, 18, pp. 121-127.

4. Manaienko, I. M., 2016. Investment support of innovative development of the power industry. Kyiv: NTUU "KPI".

5. Okhrimenko, O. O. and Manaienko, I. M., 2014. Determinants of investment support: principles, mecha- nism, efficiency. Economics of development, 1(69), pp. 34-40.

6. Sihaieva, T. Ye., 2015. Methodical approach to determining the economic efficiency of investment projects. Business Inform, 9, pp. 153-157.

7. Magnitsky, N.A. and Sidorov, S. V., 2002. Distributed model of self-developing market economy. Nonlinear Dynamics and Control, 2, pp. 258-262.

8. Tulchinskaia, S. A. and Chorniy, B. P., 2015. Mechanism of attracting investment resources in conditions of increasing threats and risks. Business Inform, 9, pp. $15-19$.

\section{Використання методичного підходу до оцінювання залучення інвестиційних ресурсів у підприємства розподілення електроенергії}

\section{С. О. Тульчинська, Н.А. Шевчук, В. В. Чорній, Б. П. Чорній}

Національний технічний університет України „Київський політехнічний інститут імені Ігоря Сікорського“, м. Київ, Україна, e-mail: tuha@ukr.net

Мета. Обгрунтувати методичний підхід до оцінки залучення інвестиційних ресурсів у підприємства розподілу електроенергії в умовах диверсифікації їх джерел на основі використання моделі нелінійної динаміки М.А. Магницького.

Методика. У процесі дослідження були використані системний і синергетичний підходи, а також метод аналітичного моделювання.

Результати. У роботі була обгрунтована можливість використання моделі нелінійної динаміки М.А. Магницького для оцінки інвестиційних проектів, запропонована структурна схема алгоритму розрахунку ефективності інвестиційного проекту підприємств розподілу електроенергії відповідно до моделі нелінійної динаміки М.А. Магницького. Запропонований методичний підхід до оцінки залучення інвестиційних ресурсів має практичну цінність як для підприємств розподілу електроенергії, так й інших підприємств, а також дає можливість визначити ефективність інвестиційного проекту в умовах диверсифікації джерел залучення інвестиційних ресурсів.

Наукова новизна. У роботі удосконалено методичний підхід до оцінки ефективності інвестиційних проектів підприємств розподілу електроенергії на когнітивно-інформаційній основі, що базується на реалізації: математичної структурної моделі розрахунку параметрів інвестиційного проекту й рішень двох диференціальних систем рівнянь моделі М.А. Магницького. Ця модель, на відміну від існуючих, базується на рішенні аттракторів Фейгембаума зі стабілізацією робочих точок управління залучення інвестиційних ресурсів на основі їх диверсифікації.

Практична значимість. Запропонований методичний підхід до оцінки залучення інвестиційних 
ресурсів може бути використаний на підприємствах для оцінки залучення інвестиційних ресурсів в умовах їх диверсифікації.

Ключові слова: інвестиційні ресурси, інвестиційний проект, нелінійна динаміка, диверсифікація, ефективність

\section{Использование методического подхода к оценке привлечения инвестиционных ресурсов на предприятия распределения электроэнергии}

\section{С. А. Тульчинская, Н.А. Шевчук, В. В. Чорней, Б. П. Чорней}

Национальный технический университет Украины „Киевский политехнический институт имени Игоря Сикорского“, г. Киев, Украина, e-mail: tuha@ukr.net

Цель. Обосновать методический подход к оценке привлечения инвестиционных ресурсов в предприятия распределения электроэнергии в условиях диверсификации их источников на основе использования модели нелинейной динамики М.А. Магницкого.

Методика. В процессе исследования были использованы системный и синергетический подходы, а также метод аналитического моделирования.

Результаты. В работе была обоснована возможность использования модели нелинейной динамики М.А. Магницкого для оценки инвестиционных проектов, предложена структурная схема алгоритма расчета эффективности инвестиционного проекта предприятий распределения электроэнергии согласно модели нелинейной динамики М.А. Магницкого. Предложенный методический подход к оценке привлечения инвестиционных ресурсов имеет практическую ценность как для предприятий распределения электроэнергии, так и других предприятий, а также дает возможность определить эффективность инвестиционного проекта в условиях диверсификации источников привлечения инвестиционных ресурсов.

Научная новизна. В работе усовершенствован методический подход к оценке эффективности инвестиционных проектов предприятий распределения электроэнергии на когнитивно-информационной основе, который базируется на реализации: математической структурной модели расчета параметров инвестиционного проекта и решений двух дифференциальных систем уравнений модели М.А. Магницкого. Эта модель, в отличие от существующих, базируется на решении аттракторов Фейгембаума со стабилизацией рабочих точек управления привлечения инвестиционных ресурсов на основе их диверсификации.

Практическая значимость. Предложенный методический подход к оценке привлечения инвестиционных ресурсов может быть использован на предприятиях для оценки привлечения инвестиционных ресурсов в условиях их диверсификации.

Ключевые слова: инвестиционные ресурсы, инвестиционный проект, нелинейная динамика, диверсификация, эффективность

Рекомендовано до публікації докт. екон. наук С. В. Войтком. Дата надходження рукопису 25.01.17. 